\title{
Translation Self-Efficacy as a Predictor of Translation Anxiety
}

\section{* Dr Ghaly, Wagdy F.}

\begin{abstract}
The current study investigates translation self-efficacy as a predictor of translation anxiety in an Egyptian context among third year and fourth year students, English language majors, at the Faculty of Languages and Translation, Pharos University, Alexandria, Egypt. The participants are 104 students during the Fall Semester 2018/2019. Participation is voluntary and anonymity is respected. Two research questions and one hypothesis are formulated to guide the study. The General Self-Efficacy scale (GSE) and the Translation Apprehension Test (TAT) are administered for data collection. The results reveal that $100 \%$ of the participants experience translation anxiety and that high levels of translation self-efficacy predict low levels of translation anxiety and vice versa. Based on the findings, recommendations for further studies are made.

Key Words: translation self-efficacy, translation anxiety, predictor

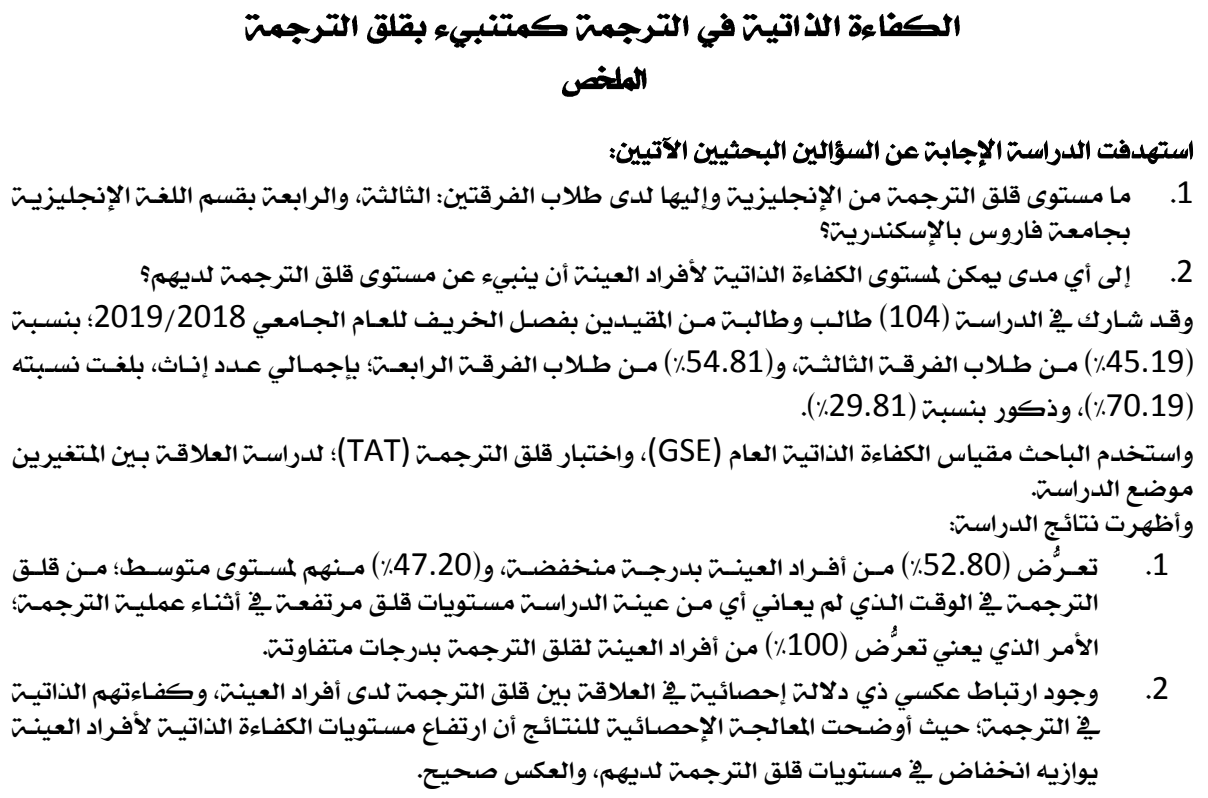

Lecture of Curriculum \& Instruction - English Language DepartmentFaculty of Languages and Translation - Pharos University, Alexandria 


\section{I.1. Introduction}

Astrong sense of selfefficacy can improve human achievement and well-being in differentways. Such an efficaciousattitudecan reduce vulnerability to anxiety, depression and worry. On the other hand, people with inadequate self-efficacy view difficult tasks as threats and, therefore, fail to pursue their goals.

Asfar as translation is concerned, Parjares and Urdan (2006) state that it has been widely recognized that the best translation is not always produced by talented translators but by those who think highly of themselves. Atranslator's final product is influenced by what s/he thinks about their competences to perform some assigned task since selfefficacy accounts for an individual's view of his/her ability to "recognize and execute the courses of action required to manage perspective situations." (Bandura, 1997:2). Unsurprisingly, translators' self-efficacy has caught researchers' attention yielding interesting results and offering some promising avenues of study in translation.

First introduced by Bandura (1979) in the field of psychology, self-efficacy is considered to be one of the relatively most recent concepts in translation studies. It is to what extent individuals believe in his/her own ability to succeed in a certain situation. It is future-oriented since it anticipates reactions in future situations and predicts one's actual performance on a task. According to Wood and Bandura (1989:408), self-efficacy is defined as "belief in one's abilities to mobilize the motivation, cognitive resources, and courses of action needed to meet given situational demands." Wood, Atkins and Tabernero (2000:431) define self-efficacy as "the belief in one's capability to execute required actions and produce outcomes for a defined task."

Haro-Soler (2017) argues that all the teachers participating in his study agree that one of the most important things for translatorsand translationstudents is to believe that they are able to produce adequate translations. Some of them believe that translators experienceanxiety and inabilityto identify a clear strategyto solve problems as one of the effects of lacking selfefficacy. All the participants agree that it is fundamental that teachers help their students trust their abilities to translate.

On the other hand, the second variable, anxiety, influences people's lives and itcan beconsidered as a part of our daily lives. It affects the mind and results in decentralization and failure to do one's tasks. People suffer from anxiety when the level of perceived threat is very high. Anxiety is described as being an unpleasant emotion which has two components: a mental component normally termed cognitive anxiety or worry, and a physiological component nomally termed somatic anxiety or physiological arousal (Woodmanand Hardy, 2001: 290-291). Janelle, Singer, and Williams (1999) confirm that 
anxious subjects often focus on irrelevant intemal and extemal information. Ravakhah, Dastjerdi and Ravakhah (2015) condude that anxiety affects translation accuracy insignificantly. Furthermore, there is a significant difference between translation speeds of translators with different levels of anxiety.

Bailey (1983) believes that researchin ESLacknowledges affective factors influence on learners' failure or success. Research has proven that foreign language learners experience significant foreign language anxiety in general (Horwitz, Horwitz \& Cape, 1986). EFL research has widely acknowledged the impact of the anxiety variable as a prospective problem in EFL classes.

Along the same lines, anxiety is a very controversial research topic in the educational research field being considered either debilitating or facilitative (Brown, 1993). It is considered a debilitating factor when it has a disruptive influence on a translator's performance. According to the opposing point of view, it is a facilitative factor when it keeps a translator alert and empowers performance. Nevertheless, it is noteworthy that most of the studies on the impact of anxiety on ESL/EFL learning have weighed heavily on the negative side of anxiety. Anxiety is believed to impair ESL/EFL learner's ability to receive process and retrieve information; this eventually influences the performance quality along with the amount of exerted effort (Maclntyre \& Gardner, 1994; Macintyre et al., 1997).

Based on the above argument, since translation education is part of EFL aumicula, it can be rightfully claimed that anxiety is a significant obstacle to students' performance in translation classes. Kim (2006:4) states that anxiety in EFL/ESL dasses also applies to translation education because it results in cognitive interference in performing certain tasks due to the distraction it causes; "If anxiety is an important factor in determining the success of languagelearning, it is also possible that it affects another field related to foreign language learning, translation". This distraction divides students' attention into taskrelated cognition and self-related cognition thus decreasing students' efficient performance. Nevertheless, while research on EFL anxiety states that anxiety impedes language learning and production, little research has been conducted on anxiety influence on translation.

With regard to self-efficacy measurement, Ivars \& Calatayud (2001); Atkinson (2012) and Medina (2014) agree that there has been no specific translation self-efficacy scales with adequate psychometric properties up till 2014. In 2014, Medina conducts a correlational study using the Spanish version of the "GSE" "to introduce the concept of selfefficacy from a social and cognitive perspective as well as to explore its possible 
implications for translation." According to Medina (2014), GSE has demonstrated a considerable internal consistency in different studies performed with international samples, which means that "total test scores would not vary significantly if slightly different items were used. Previous research has validated the use of GSE measures in various fields such as education."

Kim (2006) tests the reliability and validity of the Translation Apprehension Test (TAT). It is an adapted version of the Writing Apprehension Test (WAT) devised by Daly and Miller (1975) who originally designs it to measure students' levels of anxiety in writing courses in L1. According to Brown (1983), Kim's study also detects the relationship between translation anxiety and translation performance to see whether anxiety has a hindering or a facilitativeeffect on performance. According to Cheng, Horwitz \& Schallert (1999); Lee (2005); Mansy \& Foxall (1992), WAT proves to be a valid and reliable tool for English, Chineseand Japaneseas foreign languages. Kim's study concludes that the TAT is a reliable and valid anxiety scale in EFL translation education.

Only a few studies approach the relationship between self-efficacy and anxiety. Bandura (1997) assumes that individuals who undergo anxiety personify apprehension which interferes with their performance in their everyday life and in academic situations, too. Since a perceived sense of self-efficacy plays a significant role in arousing students' anxiety, students only experience anxiety when they believe themselves to be incapable of managing potentially difficult situations. Consistently, Murris (2002) identifies that low levels of self-efficacy are associated with high levels of anxiety. Malpass, Neil \& Hocevar (1999) state that emotional inefficacy has a bad effect on self regulation and goal orientation in academic performance. Tahmassian \& Moghadam (2011) condude that total self-efficacy, physical self-efficacy and emotional self-efficacy have a significant and negative relationship with anxiety. Moreover, they predict almost $43 \%$ of anxiety score. The results of the study show that a low sense of self-efficacy is strongly related to high levels of anxiety and is contingent with those obtained by others such as Murris (2002).

Medina and Nunez (2018) differentiate between self-efficacy and other related constructs like self-concept, selfesteem and self-evaluation of performance. They suggest that an individual's self-concept is whats/hethinks about the self.

Selfesteem involves the positive or negative evaluation of the self. While both selfconcept and self-efficacy express judgment on individuals' own abilities, the former incorporates cognitive and affective responses towards the self influenced by social comparison (Bong and Clark, 1999). Self-efficacy implies a sort of evaluation of prospective situations whereas self-evaluation deals with past performance. Bandura 
(1994) suggests four main sources of self-efficacy: mastery experiences, vicarious experiences provided by social models, social persuasion, and psychological and emotional states. Of the four sources, mastery experience seems to be the most influential as far as academic self-efficacy is concerned. Self-efficacy is positively correlated with mastery goal orientation and intrinsic motivation according to $D^{\prime}$ Lima, Winsler and Kitsantas (2014). Buch, Safvenbom and Boe (2015) assert that with increasing levels of intrinsic motivation, subjects may be more inclined to act on their selfefficacy beliefs, resulting in increased perception of competence. Although studies show that foreign language anxiety impede ESL/EFL learning and production little research has been conducted on translation.

\section{I.2. Statement of the problem}

The researcher has constantly noticed that translation students with high levels of self-efficacy, those whose behaviour shows confidence in their abilities to perform the assigned translation tasks successfully, show low levels of translation anxiety, the perception of translation tasks as the most stressful, unpleasant and the least enjoyed in their courses. Informal chatting with the researcher's colleagues has confirmed the researcher'sobservation that a considerable number of third and fourth year students at the Faculty of Languages and Translation - Pharos University in Alexandria experience translation anxiety and that translation selfefficacy among these students is inversely proportional to their translation anxiety.

Therefore, the Translation Apprehension Test (TAT) and the General Self-Efficacy Scale(GSE) (Appendices A\&B) were administered to the sample of the present study in the Fall semester of the academic year 2018/2019. The need for this study stems from the scarcity of these studies in the Egyptian context despite their significance.

\section{I.3. Research questions}

The currentstudyaims to determine the level of translation anxiety among English language department third and fourth year students at the Faculty of Languages and Translation at Pharos University-Alexandria and whether translation anxiety among the participants can be predicted by translators' self-efficacy. The present study attempts to answer the following two main questions:

a) What is the translation anxiety level of English language department third and fourth year students at the Faculty of Languages and Translation at Pharos University-Alexandria?

b) To what extent does the translation self-efficacy level of the above mentioned sample predict the subjects' translation anxiety level? 


\subsection{Research hypothesis}

Based on thesecond research question, the researcher hypothesizes the following: "There is a statistically significant correlation at $(\alpha \leq 0.05)$ between the subjects' translation self-efficacy and their translation anxiety."

\subsection{Significance of the research}

The present study is important for all the parties involved in translation courses: facultyadministration, programmeand course designers, translation tutors, stakeholders and the students themselves. The current study draws conclusions mainly from quantitative data. Moreover, no previous studies have been conducted in the Egyptian context to detect the correlation between translation self-efficacy and translation anxiety. The lack of published EFL literature in the Egyptian context could be attributed to the relative novelty of the self-efficacy concept in translation studies (Haro-Soler, 2017). To bridge this gap in the literature, this study sheds light on the relationship between translation self-efficacy and translation anxiety.

The current studymay be significant for:

\subsubsection{Translation Tutors}

The current study is an attempt to supplement translation classes where the traditional method is used with a modern student-centred approach. It attempts to attract Egyptian translation instructors' attention to the benefits of creating a supportive learning-teachingenvironment in the translation classroom to enhancethestudents' selfefficacy.

\subsubsection{Programme and Course Designers}

Thisstudy could provide methodologists and curriculum specialists with insights for the problem of translation anxiety. The study is significant as it is an attempt shed light on the impact of learners' self-efficacy on their performance and the necessity of incorporating psychological competences, in general, and self-efficacy, in particular, in translation programmes and courses in a structured way so that it can overcome the difficulty it entails. The current study attempts to cast light on the impact of translation anxiety on translation students' lack of self-efficacy which results in avoidance of translation tasks and fear of translation tasks being evaluated.

\subsubsection{Translation Students}

The presentstudyattemptsto explore translation students' self-efficacyas a means to predict students' anxiety by uncovering the correlation between translation anxiety and students' lack of self-efficacy. Moreover, it is an attempt to conduct translation 
dasses in an interesting context different from outdated boring traditional dasses. Finally, translation students can be provided with understanding of selfefficacy mechanisms so that they can observe their performance more consciously so as to be more aware of their beliefsand modify themaccordingly, to be able to create the balance between their real abilities and the confidence they have in them.

\subsection{Limitations of the study}

The study is implemented in the English language department, Faculty of Languages and Translation, Pharos University- Alexandria in the Fall Semester of the academic year 2018/2019. Only 104 students in the Junior (third year) and Senior (fourth year) Classes participate in the study as they have been studying translation for three or four years in the faculty and are expected to graduate as translators in a few months.

The current study mainly concentrates on determining whether the subjects experiencetranslation anxiety or not, how much theyexperience translation anxiety and whether this anxiety can be predicted by translation self-efficacy in an Egyptian context.

\section{Research methodology}

\subsection{Procedure}

The following procedure is followed to answer the questions of the study:

a) The literature of translation self-efficacy, translation anxiety and the impact of translation self-efficacy on translation anxiety are consulted.

b) The General Self-Efficacy Scale (GSE) is administered to the students, marked and statisticallyanalyzed.

c) The Translation Apprehension Test (TAT) is administered to the students, marked and statistically analyzed.

d) The study employs a correlational research design to test bivariate correlation between the subjects' translation self-efficacy variable and their translation anxiety variable. Pearson's correlation coefficient is used since correlational design is used in asituation where the researcherseeks toestablish the relationship between two or morevariables.

e) The results of the studyareanalyzed and interpreted.

f) Further recommendations and suggestions for research are concluded. 


\section{2. The Instruments}

In the current study, the following instruments are used:

a) The General self-efficacy scale (GSE)

The General Self-Efficacy Scale (GSE) is a ten-item likert scale which has been originally developed in German by Schwarzer and Jerusalem (1995), then revised and translated into 26 other languages. It is a uni-dimensional instrument (AppendixA) with four-point scale responses ranging from one point for (Not at all true) to 4 points for (Exactlytrue). Thescaleuses a fixed choice responseformat which enables participantsto determine their level of agreement or disagreement. Having an internal consistency of $0.79<a<0.93$ in different international studies means that using slightly different items would not vary its scores significantly. According to Sanjuan, Perez, \& Bermudez (2000), the scale has a suitable rate of reliability and a good predictive value.

b) The Translation Apprehension Test(TAT)

This test is a modified version of the Writing Apprehension Test (WAT) developed by Daly and Miller (1979). WAT is modified to fit in with translation-specific contexts (Appendix A). The participants are asked to mark their reactions to the statements on a five-point Likert scale. The test comprises of 13 positive statements (PSV) (no. 2-5-8-9-1011-13-15-17-18-21-24-and 26) and 13 negative statements (NSV) (no. 1-3-4-6-7-12-1416-19-20-22-23 and 25). To determine the test score, the point values for the positive statements are added. Then, the point values for the positive statements are added. Then, the scores are put into the formula:TA=78+PSV-NSV.

\subsection{Definition of terms}

\subsubsection{Translation self-efficacy}

In the current study, "translation self efficacy" refers to the self-perceived ability of an undergraduate translation student in performing the translation tasks assigned to him/her.

\subsubsection{Translation anxiety}

In the current study, "translation anxiety" refers to an uncomfortable feeling of apprehension or worry about an undergraduate translation student's capability to perform the future translation tasks assigned to him/her.

\subsection{Participants}

The sample of the study consists of 104 students at Faculty of Languages and Translation, Pharos University- Alexandria in the Fall Semester of the academic year 2018/2019. Of the 104 students, 47 (45.19\%) are juniors (third year students) and 57 
(54.81\%) are seniors (fourth year students) with a total number of 73 (70.19\%) females and 31(29.81\%) males. All the participants are English language major students. The university administration agreed to allow the researcher to perform thestudy (Appendix C). Participation is voluntary and anonymity is respected. The two questionnaires are completed during one course session.

\section{Results:}

3.1. Research Question 1: What is the translation anxiety level of English language department third and fourth year students in the Faculty of Languages and Translation in Pharos University-Alexandria?

\begin{tabular}{|c|c|c|c|c|c|c|c|c|}
\hline N & $\begin{array}{c}\text { Lowanxiety } \\
\text { level } \\
97-130\end{array}$ & $\begin{array}{c}\text { Medium } \\
\text { anxietylevel } \\
60-96\end{array}$ & $\begin{array}{c}\text { Highanxiety } \\
\text { level } \\
26-59\end{array}$ & $\begin{array}{c}\text { Range of } \\
\text { anxiety } \\
\text { score }\end{array}$ & $\begin{array}{c}\text { Sum } \\
\text { ofanxiety } \\
\text { score }\end{array}$ & $\begin{array}{c}\text { Meanof ototal } \\
\text { anxiety } \\
\text { score }\end{array}$ & $\begin{array}{c}\text { Std. } \\
\text { Error }\end{array}$ & Std.Dev. \\
\hline 104 & 55 & 49 & 00 & $64-122$ & 10342 & 99.44 & 1.07 & 10.95 \\
\hline
\end{tabular}

Table(1):Mean and standard deviation analysis showing the translation anxietylevel of the sample

Anxiety levels in the Translation Apprehension Test (TAT), according to Daly and Miller (1975), are divided into three levels. The low anxiety level is between 97 and 130, the medium anxiety level is between 60 and 96 and the high anxiety level is between 26 and 59. Therefore, in the currentstudy, 55 students with a percentage of 52.8 experience low anxiety level and 49 students with a percentage of 47.2 experience a significantly unusual level of anxiety whereas no students suffer from translation high anxiety level. Thus, $100 \%$ of the participants experience translation anxiety. 


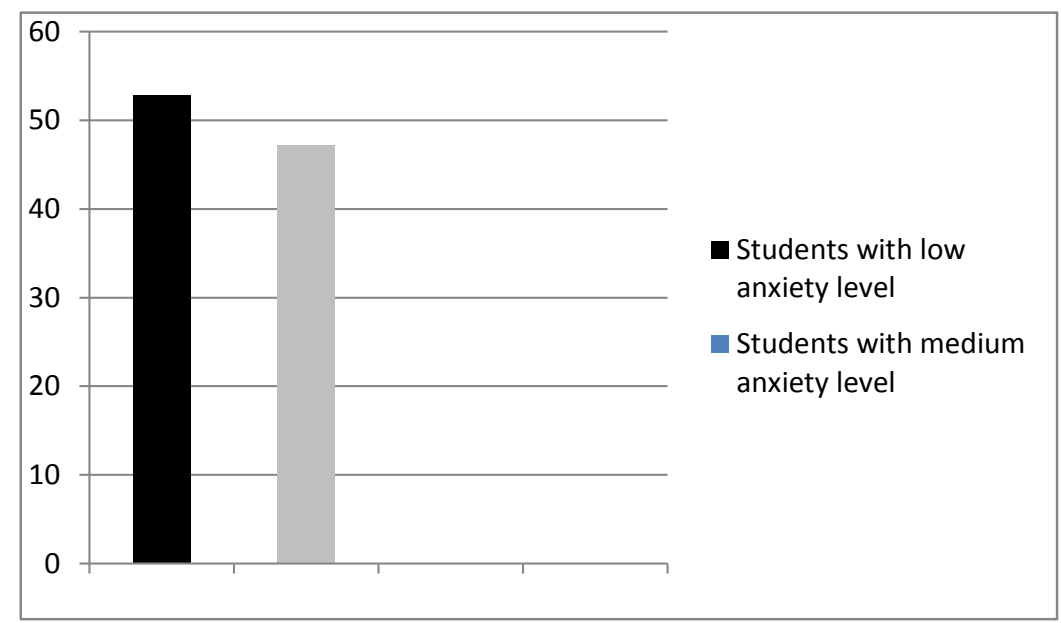

Fgure(1):Students' levels ofanxiety

\subsection{The Research Hypothesis:}

To answer the second research question, the researcher examined the following hypothesis: "There is a statistically significant correlation at $(\alpha \leq 0.05)$ between the subjects' translation self-efficacy and their translation anxiety."

Pearson Correlation Coefficient between the mean scores of the subjects' translation selfefficacyand their translation anxiety was calculated. SincetheP-Value is $<.00001$, there is astatisticallysignificant negative correlation between the subjects' translation self-efficacy and their translation anxiety at $<0.05$. 


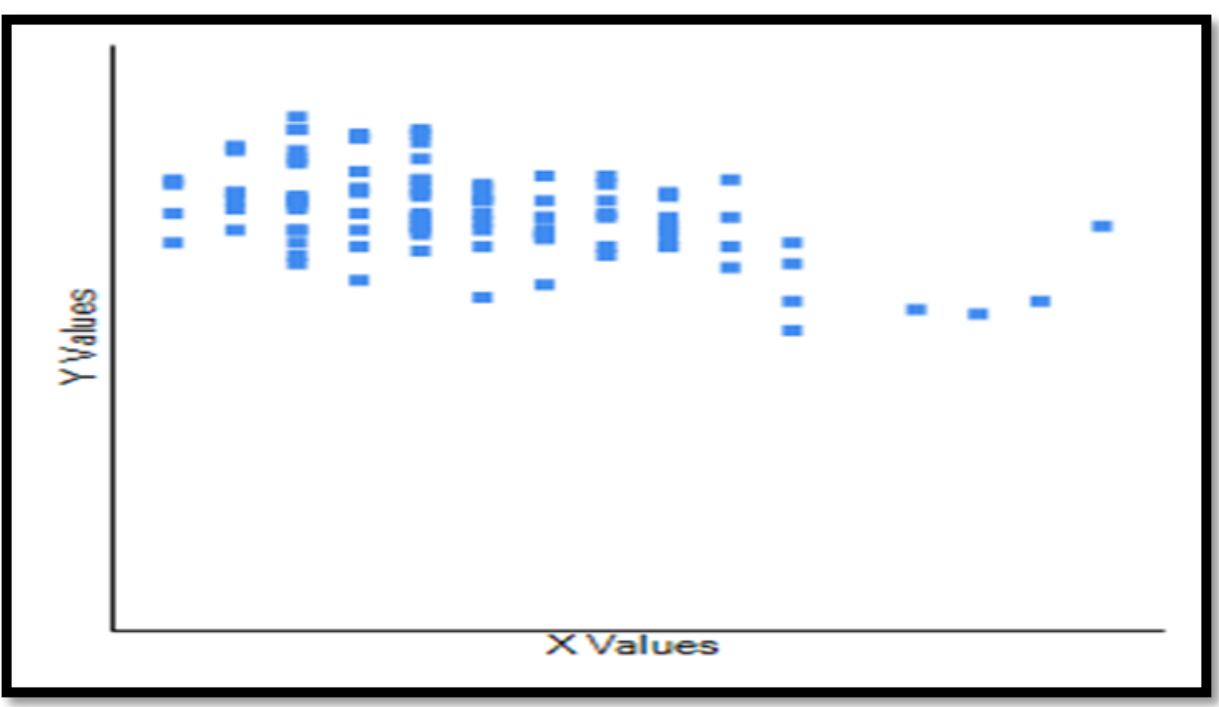

Figure(2)correlation betweenXValues(students' selfefficacy) and YValues(students' anxiety)

3.3. Research Question 2: To what extent does the translation selfefficacy level of the above mentioned sample predict the subjects' translation anxiety level?

\begin{tabular}{|c|c|c|c|}
\hline $\mathbf{N}$ & $\mathbf{R}$ & $\mathbf{R}^{2}$ & Adjusted $^{2}$ \\
\hline 104 & -0.513 & 0.26 & 0.24 \\
\hline
\end{tabular}

Table(2): Regressionanalysis of the prediction of translation selfefficacy of translation anxiety

According to the study results shown on Table (2), $R$ is -0.513 , this result indicates a moderate negative correlation between translation self-efficacy and translation anxiety. These inversely proportional scores of the two related variables mean that there is a tendency for high $X$ variable (Translation self-efficacy) scores to go with low $Y$ variable (translation anxiety) scores and vice versa. In other words, this result shows that high translation self-efficacy predicts low translation anxiety and vice versa. The coefficient of determination $\mathbf{R}^{\mathbf{2}}$ is 0.26 which shows that $26 \%$ of the variation in translation anxiety can be accounted for by translation self-efficacy.

\section{Discussion, Condusion and Recommendations}

The present study helps to anticipate the subjects' needs and devise the necessary strategies for reducing the stress that impedes the students' development. 
As far as the first research question is concerned, the current study shows that all the participants experience low and medium levels of anxiety though none of them experience a high level of anxiety.

Regarding the second question of the research and the research hypothesis, the results show that the participants who have negative expectations conceming their translation competence feel apprehensive while translating, avoid translation tasks and do notenjoy translation tasks.

Krashen (1982) has developed the theory of monitoring the model of second language development on the basis of an affective filter. Heassumes that successful SLA depends on the learner's attitude; negative attitudes like a lack of motivation or selfconfidence and anxiety act as a filter since they impede the learner from making use of input, and obstruct success in second language. According to Kim (2006), translation anxiety works negatively with achievement of students. Meanwhile, Tirkkonen-Condit and Laukkanen (1996, cited in Medina, 2014) imply that translation programmes in different universities should be designed to provide translation students with opportunities to develop positive professional confidence in themselves as well as their competence.

Therefore, building a sense of confidence in students requires creating a studentcentred dassroom where improving the students' self-efficacy is the main interest of the tutors. Moreover, students should be encouraged to manage their anxiety level by raising their level of self-efficacy which happens only in a supportive classroom environment. Teachers are also required to create anxiety-free classroom environments in which learners can be more effective translators by providing their students with the materials they like and are interested in to turn translation tasks into an enjoyable ones (Ellis 2006:541). Yates \& Pryor (2013:1) suggest taking the following measures to help students become more confident learners and minimize the potential anxiety that can bring about uncertainty and confusion:

- give an oveniew of the lesson or module

- bevery clear about the objectives

- tell learners clearly what they will be doing and why.

- be explicitabout what learners are expected to do

Using technology-based tools such as TV, radio, DVD, CD as well as organizing a computer- based teaching atmosphere is found as an effective solution for anxiety. Reducing translation learning anxiety and stimulating the students' desire to improve 
their language abilities and consequently their translation skills can be obtained by minimizing undulynegative feedbackon students' performance and maximizing positive perceptions about their competences. Students' affective factors must be taken into consideration. The findings of Hui Nis study (2012) provide evidence that affective componentsdevelop positive and valuableconcepts of self-efficacyaboutlearning, which consequently lead to further effective learning. Willingness to participate and to learn on the part of learners, and therefore further success in language performance, can be achieved through appropriate guidance and encouragement.

Besides, encouraging students' self-efficacy to grow while they are still in the relatively protective environment of the undergraduate stage is advisable since they will be able to deal with challenges and overcome problems with the help of their tutors along with their peers.

In light of the results of the present study, there are some recommendations for furtherresearch:

a) The relatively small number of the research sample (104 students) is one of the limitations of the current study; therefore a study with a larger sample is required.

b) Additional research efforts are required to explore the correlation between translation students' self-efficacy and their performance in Egyptian universities.

c) More investigation into distinguishing the impact of self-efficacy on translators from the impact of other similar concepts such as self-confidence, self-concept and selfesteem is badly needed especially in the Egyptian context.

d) A study to analyze, extract and identify the factors induded in translation anxiety through the Translation Apprehension Test (TAT) is recommended. The necessity for such a research in the Egyptian context arises from the need to acquire detailed information on the negativecorrelation between Egyptian students' translation selfefficacy and each of these factors of translationanxiety and the predictabilitylevel of each of them.

The researcher believes that translation from and into English must be taken seriously as a significant means of global interaction that helps forge interactive relationships between different nations. The current situation has resulted in a need for quality translation in diverse fields and has led to the awareness of the role the translation affective factors play in quality translation teaching and its growing importance in this era of globalization. 


\section{References}

1- Atkinson, D. (2012). Freelance Translator Success and Psychological Skill: A Study of Translators Confidence with Perspectives from Work Psychology. PhD. diss. University of Auckland.

2- Bailey, K.M. 1983. "Competitiveness and Anxiety in Adult Second Language Learning: Looking at and through the Diary Studies," 67-102 in H. Seliger and M.H. Long, eds., Classroom-Oriented Research in Second Language Acquisition. Rowley: MA: Newbury House.

3- Bandura, A. (1979). Self-referent mechanisms in social learning theory. American Psychologist, 34:439-441.

4- Bandura, A. (1994).Self-efficacy. In: Ramachaudran, V. S. (ed.) Encyclopedia of Human Behavior, 4. New York: Academic Press. 71-81.

5- Bandura, A. (1997). Self-Efficacy: The Exercise of Control. New York: Freeman.

6- Bolaños-Medina, A. (2014). Self-efficacy in Translation. Translation and Interpreting Studies Vol. 9. No. 2. 197-218.

7- Bong, M., \& Clark, R. (1999). Comparison between self-concept and self-efficacy in academic motivation research. Educational Psychologist, 34(3), 139-153.

8- Brown, A., Bransford, J., Ferrara, R., \& Campione, J. (1983). Learning, remembering, and understanding. In Flavell \& Markham (Eds.), Handbook of child psychology (Vol. 3, pp. 77-166). New York:Wiley.

9- Brown, J. (1993). Self-esteem and self-evaluation: Feeling is believing. In J. M. Suls (Ed.), The self in social perspective (pp. 27-58). Hillsdale, NJ: Erlbaum.

10- Buch, R., Säfvenbom, R., Boe, O. (2015). The relationships between academic selfefficacy, intrinsic motivation, and perceived compentence.Joumal of Military Studies, 6, 1-17.

11- Cheng, Y., Horwitz, E.K. \& Schallert, D.L (1999). Lnguage anxiety: Differntiating writing and speaking components. Language Leaming, 49(3), 417-446.

12- D'Lima, G., Winsler, A.\& Kitsantas, A.(2014). Ethnic and Gender Differences in Firstyear College Students' Goal Orientation, Self-efficacy, and Extrinsic and Intrinsic Motivation. The Joumal of Educational Research, Vol.107. No. 5.341-356.

13- Ellis, R.(2006) "Individual Differences in Second Language Leaming”, in Davies, A.\&Elder, C. The Handbook of Applied Linguistics.Pp:525-553. 
14- Haro-Soler, M. M. (2017). Teaching Practices and Translation Students' Self-Efficacy: A Qualitative Study of Teachers' Perceptions. Current Trends in Translation Teaching and LearningE, 4, 198-228.

15- Horwitz, E., Horwitz, M. and Cope, J. (1986). "Foreign Language Classroom Anxiety." Modem Language Joumal, 70:125-132

16- Hui, Ni. (2012) The Effects of Affective Factors in SLA and Pedagogical Implications. Theoryand Practice in Language Studies, Vol. 2, No. 7, pp. 1508-1513.

17- Ivars, J. \& Calatayud, D. (2011). "I failed because i got very nervous". Anxiety and performance in interpreter trainees: an empirical study. Università di Trieste.

18- Janelle, C., Singer, R. \& Williams, M. (1999). External Distraction and Attentional Narrowing: Visual Search Evidence. Journal of Sport and Exercise Psychology, 21, 70-91.

19- Kim, H. (2006). Utility of Anxiety Scales in Translation Education: Test of the Translation Apprehension Test(TAT). Conference Interpretation and Translation,8(1), 45-60.

20- Krashen, S. (1982). Principles and practice in second language acquisition. New York: Prentice-Hall International.

21- Lee, S. (2005). Facilitating and inhibiting factors in English as a foreign language writing performance: A model testing with structural equation modeling. Language Leaming, 55(2), 335-374.

22- Madntyre, P., \& Gardner, R. (1994). The subtle effects of language anxiety on cognitive processing in the second language. Language Leaming, 44, 283-305.

23- Madntyre, P., Noels, K., \& Cément, R. (1997). Biases in self-ratings of second language proficiency: The role of language anxiety. Language Learning, 47, 265-287.

24- Masny, D., \& Foxall, J. (1992). Writing apprehension in L2. (ERIC Document Reproduction Senvice No. ED 352 844).

25- Malpass, J., Neil, H. \& Hocevar, D. (1999). Goal orientations, self-efficacy, worry, and high tasks mathematically gifted high school students. Roeper Review; 21(4):281-8.

26- Muris, P. (2002). Relationship between self-efficacy and symptoms of anxiety disorders and depression in a normal adolescent sample. Personality and Individual Differences, 32,337-348.

27- Núñez,J., \& Medina,A. (2018).Predictorsof problem-solving in translation: implications fortranslatortraining. The Interpreterand Translator Trainer, 12(3), 282-298.

28- Pajares, F.\& Urdan, T. 2006. Self-efficacy Beliefs of Adolescents. Greenwich: Information Age Pub. 
29- Ravakhah, A., Dastjerdi, V. \& Ravakhah, M. (2015). Translation and Anxiety: A Study of Anxiety Effect on Translators' Performance in Terms of Speed and Accuracy. Theory and Practice in Language Studies, Vol. 5, No. 5, pp. 1053-1059.

30- SanjuanS., PerezG., Bermudez, J., (2000). Thegeneral self-efficacy scale: psychometric data from the Spanish adaptation. Psicothema 12, 509-513.

31- Tahmassian, K. \& Moghadam, J. (2011): Relationship between self-efficacy and symptoms of anxiety, depression, worry and social avoidance in a normal sample of students. Iran J. PsychiatryBehav. Sa. 5: 91-98.

32- Trikkonen-Condit \& Laukkanen, J. (1996). Evaluations- A Key to Understanding the Affective Dimensions of Translational Decisions." Meta 41 (1):45-49.

33- Wood, R., \&Bandura,A. (1989). Social cognitive theory of organizational management. Academy of Management Review, 14(3), 361-384.

34- Wood, R., Atkins, P. \& Tabernero, C. (2000). Self-Efficacy and Strategy on Complex Tasks. Applied Psychology: An Intemational Review, 49, 3, 430-446.

35- Woodman, T. and Hardy, L. (2001). Stress and Anxiety, in Singer, R., Hausenblas, H. \& Janelle, C. eds., Handbook of Sport Psychology, 2nd edition (New York: Wiley), 290-318.

36- Yates, L \& Pryor, L (2013). Fact Sheet 2: building confidence in the classroom. Series: Building confidence in the classroom and beyond. AMEP Longitudinal Study, Macquarie University. Retrieved May 8, 2019 from: http://www.neas.org.au/wpcontent/uploads/Building-Confidence-Fact-Sheet-2.pdf 


\section{APPENDIX(A) \\ General Self-Efficacy Scale (GSE)}

About: This scale is a self-reportmeasure of self-efficacy.

Items: 10

Reliability: Internal reliability for GSE = Cronbach's alphas between .76 and .90

Validity: The General Self-Efficacy Scale is correlated to emotion, optimism, and work satisfaction. Negative coefficients were found for depression, stress, health complaints, burnout, and anxiety.

\section{Scoring:}

\begin{tabular}{|l|c|c|c|c|}
\hline & Notatall true & Hardlytrue & Moderatelytrue & Exactlytrue \\
\hline Allquestions & 1 & 2 & 3 & 4 \\
\hline
\end{tabular}

The total score is calculated by findingthe sum of all the items. For the GSE, the total score ranges between 10 and 40 , with a higher score indicating more selfefficacy.

References: Schwarzer, R., \& Jerusalem, M. (1995). Generalized Self-Efficacy scale. In J. Weinman, S. Wright, \& M. Johnston, Measures in health psychology: A user's portfolio. Causal and control beliefs (pp. 35-37). Windsor, UK: NFER-NELSON.

\section{General Self-Efficacy Scale(GSE)}

\begin{tabular}{|c|c|c|c|}
\hline \multirow{2}{*}{\begin{tabular}{|l|} 
\\
$\begin{array}{l}\text { 1. I can always manage to solve difficult problems ifl } \\
\text { tryhard enough. }\end{array}$ \\
\end{tabular}} & Notatall true Hardlytrue & Moderatelytrue & Exactlytrue \\
\hline & & & \\
\hline $\begin{array}{l}\text { 2. If someoneopposes me, I can find the means and } \\
\text { ways toget what I want. }\end{array}$ & & & \\
\hline $\begin{array}{l}\text { 3.Itiseasy for metostick to myaimsand accomplish } \\
\text { mygoals. }\end{array}$ & & & \\
\hline $\begin{array}{l}\text { 4. I am confident that I could deal efficiently with } \\
\text { unexpectedevents. }\end{array}$ & & & \\
\hline $\begin{array}{l}\text { 5. Thanks to my resourcefulness, I know how to } \\
\text { handleunforeseensituations. }\end{array}$ & & & \\
\hline $\begin{array}{l}\text { 6. I can solve most problems if l invest the necessary } \\
\text { effort. }\end{array}$ & & & \\
\hline $\begin{array}{l}\text { 7.Ican remain calm when facing difficalties becausel } \\
\text { can relyonmy coping abilities. }\end{array}$ & & & \\
\hline $\begin{array}{l}\text { 8. When I am confronted with a problem, I can } \\
\text { usually find several solutions. }\end{array}$ & & & \\
\hline 9.Iflam in trouble, Ican usuallythink of asolution. & & & \\
\hline 10. Ican usually handlewhatevercomesmyway. & & & \\
\hline
\end{tabular}




\section{APPENDIX(B) \\ Translation ApprehensionTest(TAT) Directions}

Belowaretwentysix statementsthat peoplesometimesmake about themselves. Please indicate whether or not you believe each statement applies to you by marking whether you: Strongly Disagree =1; Disagree=2; are Neutral=3; Agree =4; Strongly Agree= 5 .

\begin{tabular}{|c|c|c|c|c|c|c|}
\hline No. & STATEMENIS & $\begin{array}{l}\text { Strongly } \\
\text { Disagree }\end{array}$ & Disagree & Neutral & Agree & $\begin{array}{l}\text { Strongly } \\
\text { Agree }\end{array}$ \\
\hline 1 & lavoid translating. & & & & & \\
\hline 2 & Ihaveno fear of translation work beingevaluated. & & & & & \\
\hline 3 & $\begin{array}{l}\text { Iam afraid of translation texts when I know they will } \\
\text { beevaluated. }\end{array}$ & & & & & \\
\hline 4 & $\begin{array}{l}\text { Taking a translation course is a very frightening } \\
\text { experience. }\end{array}$ & & & & & \\
\hline 5 & $\begin{array}{l}\text { Handling in a translation assignment makes me feel } \\
\text { good. }\end{array}$ & & & & & \\
\hline 6 & $\begin{array}{l}\text { Mymind seems togo blank when I start to work on } \\
\text { atranslation text. }\end{array}$ & & & & & \\
\hline 7 & $\begin{array}{l}\text { Translating from one language to another seems to } \\
\text { beawaste of time. }\end{array}$ & & & & & \\
\hline 8 & $\begin{array}{l}\text { I would enjoy sending my translation to magazines } \\
\text { to beevaluated and published. }\end{array}$ & & & & & \\
\hline 9 & lenjoytranslating. & & & & & \\
\hline 10 & $\begin{array}{l}\text { I feel confident in my ability to express the meaning } \\
\text { of theoriginal text intoanother language. }\end{array}$ & & & & & \\
\hline 11 & Ilike to havemyfriends read what I have translated. & & & & & \\
\hline 12 & lamnenousabouttranslating. & & & & & \\
\hline 13 & Peopleseem toenjoy what Itranslate. & & & & & \\
\hline 14 & $\begin{array}{l}\text { I never seem able to dearly write down my ideas } \\
\text { when Itranslate. }\end{array}$ & & & & & \\
\hline 15 & Translatingisa lot offun. & & & & & \\
\hline 16 & $\begin{array}{l}\text { I expect to do poorly in translation dasses even } \\
\text { beforelenterthem. }\end{array}$ & & & & & \\
\hline 17 & Ilikeseeingmytranslation on paper. & & & & & \\
\hline 18 & $\begin{array}{l}\text { Discussingmytranslation with othersis an enjoyable } \\
\text { experience. }\end{array}$ & & & & & \\
\hline 19 & $\begin{array}{l}\text { I have a temible time organizing my ideas in a } \\
\text { translationcourse. }\end{array}$ & & & & & \\
\hline 20 & $\begin{array}{l}\text { When I hand in a translation text, I know l am going } \\
\text { togeta lowgrade. }\end{array}$ & & & & & \\
\hline 21 & It iseasy formeto writegood translation. & & & & & \\
\hline
\end{tabular}




\begin{tabular}{|c|l|l|l|l|l|l|}
\hline 22 & Idonotthink Itranslateaswell asmostpeople. & & & & & \\
\hline 23 & Idonotlikemytranslation tobeevaluated. & & & & & \\
\hline 24 & $\begin{array}{l}\text { Itry to get my translation assignments done ahead } \\
\text { of the due date rather than procrastinate until the } \\
\text { lastminute. }\end{array}$ & & & & & \\
\hline 25 & Iamnogoodattranslation. & & & & & \\
\hline 26 & $\begin{array}{l}\text { I go over my translation and the instructor's } \\
\text { commentsafter Ireceivetheassignment. }\end{array}$ & & & & & \\
\hline
\end{tabular}




\section{APPENDIX(C)}

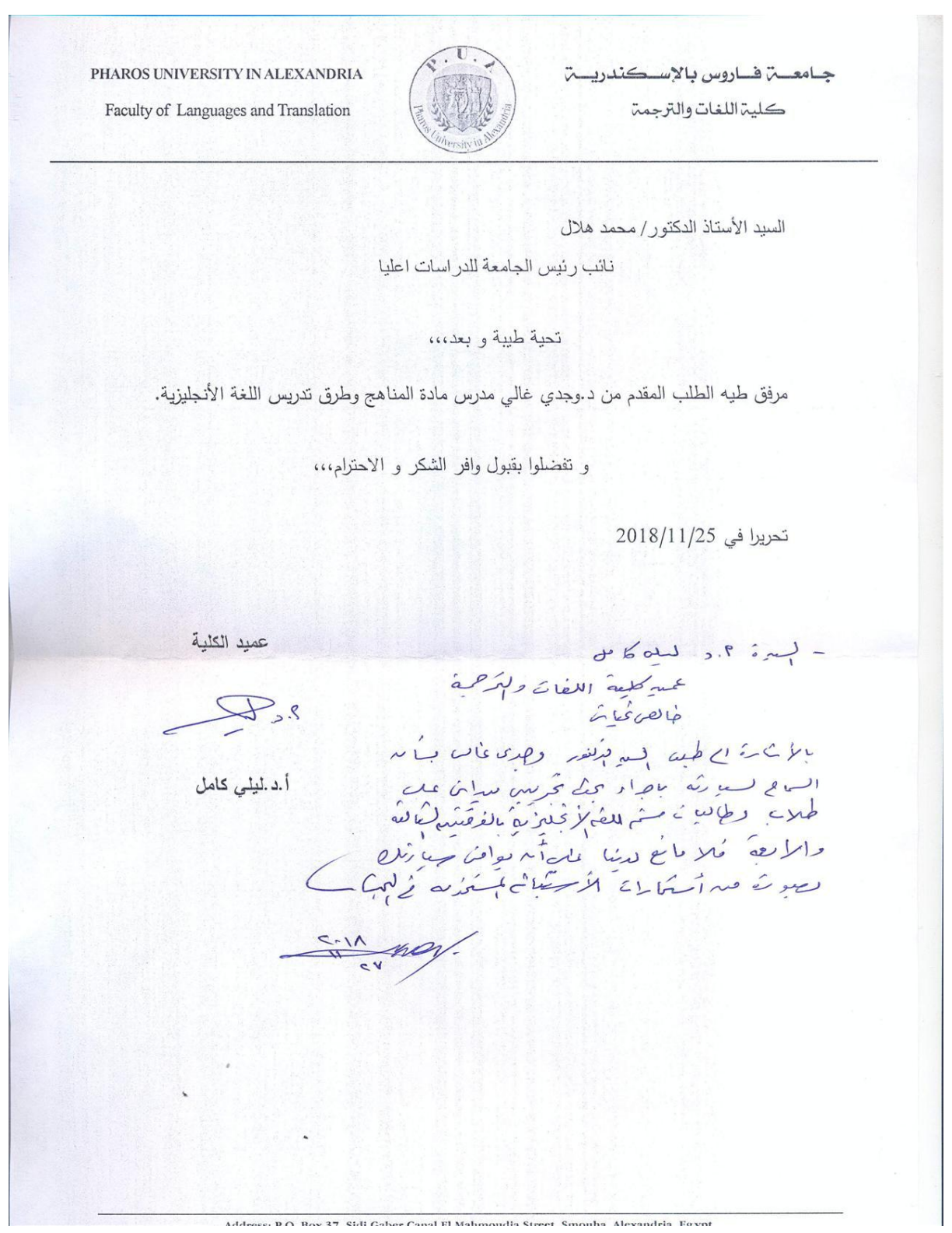

